\title{
PENGARUH MODEL PEMBELAJARAN KONTEKSTUAL TERHADAP HASIL BELAJAR SISWA PADA KOMPETENSI DASAR MENCATAT TRANSAKSI DALAM JURNAL UMUM. \\ (Studi kasus pada siswa kelas XI IPS SMA Angkasa Lanud Husein Sastranegara Bandung tahun 2013/2014)
}

\author{
Rensi Yulizah \\ Leni Yuliyanti
}

\begin{abstract}
ABSTRAK
Penelitian ini bertujuan untuk mengetahui pengaruh model pembelajaran kontekstual terhadap hasil belajar. Pengaruh ini dapat dilihat pada perbedaan hasil belajar siswa pada kompetensi dasar mencatat transaksi pada jurnal umum mata pelajaran akuntansi yang diterapkan pada siswa kelas XI IPS A dan XI IPS D SMA Angkasa.

Metode yang digunakan dalam penelitian ini quasi eksperimen dengan kelompok eksperimen dan kontrol dengan hanya pascates. Pengujian hipotesis menggunakan Uji $t$. Hasil penelitian menunjukkan, rata-rata hasil belajar siswa pada kelas eksperimen ialah 78,13 , sedangkan rata-rata nilai kelas kontrol 74. Perhitungan uji $t$ dk 78 dan taraf kepercayaan 95\% menunjukkan $t$ hitung 4,26 dan $t$ tabel 1,99 sehingga terdapat perbedaan hasil belajar siswa yang menggunakan model pembelajaran kontekstual dengan siswa yang tidak mendapatkannya. Dengan adanya perbedaan yang signifikan tersebut maka model pembelajaran kontekstual berpengaruh terhadap hasil belajar. Dengan terdapatnya pengaruh tersebut maka model tersebut dapat digunakan oleh guru yang lainnya dalam pembelajaran akuntansi
\end{abstract}

Kata Kunci : Model Pembelajaran Kontekstual, Hasil Belajar 


\section{Pendahuluan}

Pendidikan merupakan proses mengembangkan dirinya yang dilakukan manusia. Tujuan pendidikan yang tertuang dalam pembukaan UndangUndang Dasar 1945, yaitu: "Mencerdaskan Kehidupan Bangsa".

Kegiatan secara riil yang mampu mengaplikasikan kegiatan komunikasi antara siswa dengan guru itu sendiri, dapat mewujudkan tujuan pendidikan. Berhasil tidaknya tujuan pendidikan banyak tergantung kepada bagaimana proses belajar yang dialami oleh siswa sebagai peserta didik. Seperti yang diungkapkan oleh Syah, M ( 2003 :63) "Belajar adalah kegiatan yang berproses dan merupakan unsur yang sangat fundamental dalam penyelenggaraan setiap jenis dan jenjang pendidikan". Ini berarti, berhasil atau gagalnya pencapaian tujuan pendidikan itu tergantung pada proses belajar yang dialami oleh siswa.

Tujuan pendidikan dikatakan berhasil apabila para peserta didiknya memperoleh hasil belajar yang baik. Menurut Purwanto (2008 : 44) "Hasil belajar ini sering kali digunakan sebagai ukuran untuk mengetahui seberapa jauh seseorang menguasai bahan yang sudah diajarkan". Hasil belajar siswa menggambarkan sejauh mana tujuan pendidikan itu tercapai, apakah sudah tercapai dengan baik atau sebaliknya.

Sekolah Menengah Atas (SMA) Angkasa Lanud Husein Sastranegara (LHS). SMA Angkasa merupakan salah satu lembaga pendidikan formal SMA swasta dimana sudah terakreditasi "A". Berdasarkan pra penelitian yang dilakukan penulis mengenai proses kegiatan belajar di kelas, bahwa masih kurangnya respon siswa terhadap mata pelajaran Akuntansi, siswa cenderung pasif dan kurang antusias untuk bertanya atau mendiskusikan kesulitan yang mereka hadapi dalam mempelajari akuntansi dengan gurunya. Fenomena ini menunjukkan bahwa tujuan pendidikan yang tercantum di atas akan sulit untuk diwujudkan. Hal ini pun terlihat dari nilai hasil belajar siswa berupa nilai Ujian Tengah Semester (UTS) yang masih berada di bawah Kriteria Ketuntasan Minimal (KKM)

Tabel 1

Nilai Rata-rata Siswa Kelas XI IPS

Mata Pelajaran Akuntansi

Tahun Ajaran 2013 - 2014

SMA ANGKASA

(Berdasarkan Nilai UTS)

\begin{tabular}{|c|c|c|c|c|c|}
\hline \multicolumn{5}{|c|}{ KKM 75 } \\
\hline No & Kelas & Jumlah Siswa & $<75$ & $\geq 75$ & $\begin{array}{c}\text { Di bawah } \\
\text { KKM } \\
(\%)\end{array}$ \\
\hline 1 & XI IPS A & 40 & 25 & 15 & $62,5 \%$ \\
\hline 2 & XI IPS B & 40 & 18 & 22 & $45,0 \%$ \\
\hline 3 & XI IPS C & 40 & 16 & 24 & $40,0 \%$ \\
\hline 4 & XI IPS D & 40 & 26 & 14 & $65,0 \%$ \\
\hline
\end{tabular}

Diolah dari arsip nilai guru Akuntansi kelas XI IPS SMA Angkasa 
Dapat dilihat dari Tabel 1.1 bahwa nilai UTS akuntansi siswa masih terdapat siswa yang nilainya di bawah KKM, seperti pada kelas XI IPS A dengan jumlah siswa 40 siswa, hampir 25 siswa yang tidak mencapai KKM. Kelas XI IPS B ada 18 siswa yang tidak mencapai KKM, untuk kelas XI IPS C hanya 16 siswa saja yang belum mencapai KKM, dan Kelas XI IPS D dengan jumlah siswa 40 orang ada 26 siswa yang nilai UTS nya belum mencapai KKM.

Nilai yang masih di bawah KKM tersebut akan memberikan dampak pada siswa bahkan sekolah itu sendiri. Dampak yang ditimbulkan dari masalah tersebut ialah, siswa akan kesulitan dalam melanjutkan materi akuntansi selanjutnya, karena materi akuntansi merupakan sebuah siklus yang saling berhubungan. Sehingga untuk memahami materi akuntansi selanjutnya siswa harus memahami materi sebelumnya, bahkan jika siswa tidak memahami materi tersebut akan berdampak pada nilai.

Rendahnya hasil belajar tersebut disebabkan oleh banyak faktor diantaranya faktor instern dan faktor ekstern. Salah satu faktor ektern adalah sekolah yang didalamnya termasuk model pembelajaran yang digunakan guru dalam mengajar.

Penerapan model pembelajaran yang kurang tepat akan membuat siswa kurang memahami dalam pembelajaran akuntansi. Siswa pun akan kurang aktif dalam pembelajaran, keaktifan ini dapat digambarkan dengan adanya kegiatan siswa bekerja dan mengalami, tidak hanya memberikan pengetahuan dari guru ke siswa. Menurut Sahuri (2009) "Pengetahuan bukan sebuah kumpulan fakta, konsep, atau kaidah yang sudah siap untuk diambil, diingat atau dihafal, tetapi manusia perlu mengaplikasikan dalam dunia nyata".

Model pembelajaran yang sesuai merupakan salah satu penentu keberhasilan dalam kegiatan belajar mengajar. Menurut pemaparan Wahab (2009 : 52) "model pembelajaran adalah sebuah perencanaan pengajaran yang menggambarkan proses yang ditempuh pada proses belajar mengajar agar dicapai perubahan spesifik pada perilaku siswa seperti yang diharapkan".

Guru menentukan model yang mengaitkan antara materi yang diajarkannya dengan situasi dunia nyata siswa. Sehingga dapat mendorong siswa membuat hubungan antara pengalaman dengan penerapannya dalam kehidupan mereka. Hal ini lah yang mendasari pengembangan model pembelajaran kontekstual atau Contextual Teaching and Learning yakni konsep belajar yang menghubungkan antara materi yang diajarkan oleh pendidik dengan situasi dunia nyata siswa.

Kompetensi dasar mencatat transaksi atau dokumen pada jurnal umum merupakan materi yang cukup menarik dan sesuai untuk dijadikan bahan penelitian, karena materi tersebut dapat di terapkan pada kehidupan siswa sehari-hari.

Berdasarkan latar belakang masalah yang telah diungkapkan di atas, maka rumusan masalah pada penelitian ini adalah apakah terdapat perbedaan hasil belajar siswa yang mendapatkan pembelajaran kontekstual dengan siswa yang tidak mendapatkan pembelajaran kontekstual pada mata pelajaran akuntansi.

Maksud diadakanya penelitian ini adalah untuk mengetahui bagaimana pengaruh model pembelajaran kontekstual pada hasil belajar siswa. Sedangkan tujuan diadakannya penelitian ini adalah untuk mengetahui perbedaan hasil belajar antara siswa yang mendapatkan pembelajaran kontekstual dengan siswa yang tidak mendapatkan pembelajaran kontekstual pada mata pelajaran akuntansi.

\section{Landasan Teoritis, Kerangka Pemikiran dan Hipotesis Belajar}

Belajar dalam teori konstruktivisme bukanlah sekedar menghafal akan tetapi proses mengkonstruksi pengetahuan melalui pengalaman. Teori belajar konstruktivisme mengakui bahwa siswa akan dapat menginterpretasikan informasi kedalam pikirannya, hanya pada konteks pengalaman dan pengetahuan mereka sendiri, pada kebutuhan, latar belakang, dan minatnya.

Dalam dunia pendidikan kegiatan belajar dan pembelajaran adalah suatu proses yang tidak dipisahkan. Hal ini karena melalui proses tersebut dapat terwujud sumber daya manusia yang berkualitas. Belajar dapat didefinisikan sebagai suatu proses perubahan tingkah laku individu melalui interaksi dengan lingkungan. Sedangkan menurut pandangan Skiner (dalam Sagala, 2006:14) mendefinisikan bahwa "belajar adalah suatu proses adaptasi atau penyesuaian tingkah laku yang berlangsung secara progresif. Belajar juga dipahami sebagai suatu perilaku, pada saat orang belajar, 
maka responsnya menjadi lebih baik". Sedangkan menurut Hamalik (2001:27) mendefinisikan bahwa "belajar adalah modifikasi atau memperteguh kelakuan melalui pengalaman (learning is defired as the modofication or strengthening of behavior through experiencing)".

Knirk dan Gustafson (dalam Sagala, 2006:64) mengemukakan tentang konsep pembelajaran sebagai berikut "Teknologi pembelajaran melibatkan tiga komponen utama yang saling berinteraksi yaitu guru (pendidik), siswa (peserta didik), dan kurikulum". Komponen tersebut melengkapi struktur dan lingkungan belajar formal. Hal ini dapat disimpulkan bahwa pembelajaran adalah setiap kegiatan yang dirancang oleh guru untuk membantu seseorang mempelajari suatu kemampuan dan atau nilai yang baru dalam suatu proses yang sistematis melalui tahap rancangan, pelaksanaan, dan evaluasi dalam konteks kegiatan belajar mengajar. Oleh sebab itu dalam komponen pembelajaran seorang guru mempunyai peran yaitu sebagai sumber belajar, fasilitator, seorang manajer, demonstrator, motivator, dan evaluator.

\section{Hasil Belajar}

Hasil belajar merupakan perubahan perilaku siswa karena telah mengalami proses belajar. Perubahan itu diupayakan untuk mencapai tujuan pendidikan. Menurut Purwanto (2008 : 34) "hasil belajar merupakan perubahan perilaku siswa akibat belajar. Perubahan itu diupayakan dalam proses belajar mengajar untuk mencapai tujuan pendidikan". Selain itu menurut Sanjaya (2006:27) menyatakan bahwa "hasil belajar merupakan gambaran kemampuan siswa dalam memenuhi suatu tahapan pencapaian pengalaman belajar dalam satu kompetensi dasar". Maka dapat disimpulkan bahwa hasil belajar siswa ini mengindikasikan sejauh mana tujuan pendidikan itu tercapai, apakah sudah tercapai dengan baik atau sebaliknya.

Ada beberapa faktor yang mempengaruhi hasil belajar, menurut Slameto (2010:54) bahwa:

Faktor-faktor yang mempengaruhi hasil belajar siswa banyak jenisnya, tetapi dapat digolongkan menjadi dua golongan saja, yaitu faktor intrinsik dan faktor ekstrinsik.
1. Faktor intrinsik adalah faktor yang berada dalam diri individu yang sedang belajar. Faktor internal yang mempengaruhi belajar meliputi: faktor jasmani (faktor kesehatan cacat tubuh), faktor psikologi (intelligensi, perhatian, minat, bakat, motif, kematangan, dan kesiapan) dan faktor kelelahan.

2. Faktor ekstrinsik adalah faktor yang ada di luar individu. Faktor eksternal meliputi: faktor keluarga (cara orang tua mendidik, relasi antar anggota keluarga, suasana rumah, keadaan ekonomi keluarga, pengertian orang tua, dan latar belakang kebudayaan), faktor sekolah (model mengajar, kurikulum, relasi guru dengan siswa, alat pelajaran, waktu sekolah, standar pelajaran di atas ukuran, keadaan gedung, model belajar, tugas rumah), dan faktor masyarakat (kegiatan siswa dalam masyarakat, teman bergaul, bentuk kehidupan masyarakat).

Sedangkan Menurut Sudjana (2006:39) faktor-faktor yang mempengaruhi hasil belajar juga terdiri dari faktor intern dan faktor ekstern, yaitu:

1. Faktor intern meliputi:
a. Kemampuan siswa
b. Motivasi belajar
c. Minat dan perhatian
d. Sikap dan kebiasaan belajar
e. Ketekunan
f. Sosial ekonomi
g. Fisik dan psikis

2. Faktor ekstern meliputi:
a. Guru
b. Kurikulum
c. Lingkungan
d. Media
e. Sosial
f. Model pembelajaran
Dari beberapa faktor yang mempengaruhi hasil belajar salah satunya adalah faktor sekolah yaitu faktor guru yaitu model pembelajaran yang dilaksanakan.

\section{Model Pembelajaran Kontekstual}

Seperti yang diungkapkan oleh Marlina (2011), bahwa "Pembelajaran kontekstual (Contextual Teaching and Learning) adalah konsep belajar yang membantu guru mengaitkan antara materi yang diajarkannya dengan situasi dunia 
nyata siswa dan mendorong siswa membuat hubungan antara pengetahuan yang dimilikinya dengan penerapannya dalam kehidupan mereka sehari-hari, dengan melibatkan tujuh komponen utama pembelajaran efektif, yakni: konstruktivisme (Constructivism), bertanya (Questioning), menemukan (Inquiri), masyarakat belajar (Learning Community), pemodelan (Modeling), dan penilaian sebenarnya (Authentic Assessment)"

Model pembelajaran berfungsi sebagai rancangan dalam melaksanakan proses pembelajaran, dan menyampaikan isi pelajaran kepada siswa untuk mencapai tujuan tertentu yang sudah ditentukan sebelumnya.

Model pembelajaran yang efektif sangat diperlukan untuk mengembangkan dan meningkatkan hasil belajar sesuai dengan apa yang diharapkan. Harapan setiap pendidik ialah anak didiknya mendapatkan hasil belajar yang baik, oleh karena itu guru harus menentukan model belajar yang tepat, sehingga materi yang disajikan dapat tersampaikan dengan baik dan tujuan yang sudah ditentukan tercapai. Penerapan model pembelajaran yang tepat dapat membuat siswa lebih aktif dalam pembelajaran, sedangkan penggunaan model yang tidak tepat akan menghambat proses belajar mengajar.

Manfaat dari penerapan model pembelajaran yang sesuai dengan materi yang akan disampaikan ialah membantu pendidik untuk menyampaikan materi dalam bentuk yang berbeda, sehingga siswa dapat belajar lebih aktif. Memahami materi pelajaran akuntansi khususnya dalam materi mencatat transaksi pada jurnal umum dengan baik ialah dengan cara mengadopsi materi akuntansi ke kehidupan nyata atau ke kehidupan siswa yang sebenarnya, karena pengetahuan akan lebih terlihat manfaatnya ketika siswa mengalami, bukan hanya menerima dan menghapal setiap ilmu yang diberikan oleh pendidik.

Belajar dalam teori konstruktivisme bukanlah sekedar menghafal, tetapi adanya proses mengkonstruksi pengetahuan melalui pengalaman, hal ini membuat siswa dapat menyimpan informasi dalam pikirannya. Model pembelajaran yang menghubungkan mata pelajaran dengan situasi sebenarnya adalah pembelajaran kontekstual. Dimana model kontekstual atau Contextual Teaching and Learning (CTL) adalah salah satu model pembelajaran yang menghubungkan materi pembelajaran dengan situasi kehidupan nyata siswa, sesuai dengan pengalamannya.

Kenyataannya dalam peroses pembelajaran, pengetahuan yang sudah diberikan oleh pendidik, hanya dianggap sebagai kumpulan ilmu yang harus dihapal, sehingga model ceramah merupakan model yang biasa diterapkan oleh para pendidik. Tetapi pada mata pelajaran akuntansi, model ceramah kurang bisa membuat siswa lebih paham dan aktif, karena mata pelajaran akuntansi lebih memusatkan siswa kepada logikanya untuk bekerja dalam menyelesaikan soal-soal. Oleh karena itu model pembelajaran kontekstual dipromosikan menjadi alternatif model belajar yang baru, guna meningkatkan hasil belajar siswa. Menggunakan model kontekstual ini, siswa diharapkan belajar melalui apa yang dialami bukan hanya menghafal, karena pembelajaran kontekstual menekankan pada pengalaman nyata siswa.

Siswa perlu mengerti apa makna, manfaat, dan bagaimana cara mencapainya kelak. Siswa lebih tertarik karena mereka mempelajari apa yang bermanfaat bagi dirinya. Berdasarkan uraian di atas dijelaskan bahwa model kontekstual merupakan alternatif yang dapat diterapkan guna meningkatan hasil belajar siswa.

\section{Kerangka Pemikiran}

Hasil belajar merupakan perubahan perilaku siswa akibat belajar. Perubahan itu diupayakan dalam proses belajar mengajar untuk mencapai tujuan pendidikan. Berhasil tidaknya seorang siswa meraih hasil belajarnya tergantung dari banyak hal atau tergantung dari faktor-faktor yang mempengaruhinya.

Ada beberapa faktor yang mempengaruhi hasil belajar salah satunya adalah faktor sekolah yaitu faktor guru yaitu model pembelajaran. Sesuai dengan faktor-faktor yang ada, faktor sekolah khususnya model mengajar adalah salah satu faktor yang mempengaruhi hasil belajar siswa, yaitu faktor ekstrinsik.

Model pembelajaran berfungsi sebagai pedoman perancangan dan pelaksanaan pembelajaran, serta cara dalam menyajikan (menguraikan, memberi contoh, dan memberi latihan) isi pelajaran kepada siswa untuk mencapai tujuan tertentu. Model pembelajaran yang efektif sangat diperlukan untuk mengembangkan 
dan meningkatkan hasil belajar sesuai dengan apa yang diharapkan.

Dalam proses belajar mengajar setiap guru senantiasa mengharapkan anak didiknya dapat mencapai hasil belajar yang semaksimal mungkin. Guru harus mampu memilih dan menentukan model belajar yang tepat. Sehingga materi yang disajikan sesuai dengan tujuan yang diharapkan. Pemakaian model pembelajaran yang tepat dapat meningkatkan keaktifan siswa dalam pembelajaran, sedangkan penggunaan model yang tidak tepat akan menghambat proses belajar mengajar.

Manfaat dari model pembelajaran secara umum dapat membantu guru untuk menyampaikan materi dalam bentuk yang berbeda, sehingga dapat membuat siswa belajar secara aktif sesuai dengan kompetensi yang sudah ditentukan oleh kurikulum, khususnya dalam mata pelajaran akuntansi. Memahami materi pelajaran akuntansi khususnya dalam materi mencatat transaksi pada jurnal umum dengan baik ialah dengan cara mengadopsi materi akuntansi ke kehidupan nyata atau ke kehidupan siswa yang sebenarnya, karena pengetahuan bukan sebuah kumpulan fakta, konsep, atau kaidah yang sudah siap untuk diambil, dingat atau dihafal, tetapi manusia perlu mengaplikasikan dalam dunia nyata.

Belajar dalam teori konstruktivisme bukanlah sekedar menghafal akan tetapi proses mengkonstruksi pengetahuan melalui pengalaman. Teori belajar konstruktivisme mengakui bahwa siswa akan dapat menginterpretasikan informasi kedalam pikirannya, hanya pada konteks pengalaman dan pengetahuan mereka sendiri, pada kebutuhan, latar belakang, dan minatnya.

Model pembelajaran yang menghubungkan mata pelajaran dengan situasi sebenarnya adalah pembelajaran kontekstual. Dimana model kontekstual atau Contextual Teaching and Learning (CTL) adalah suatu model pembelajaran yang menekankan kepada proses keterlibatan peserta didik secara penuh untuk dapat menemukan materi yang dipelajari dan menghubungkannya dengan situasi kehidupan nyata sehingga mendorong peserta didik untuk dapat menerapkannya dalam kehidupan mereka.

Dalam kenyataannya pengetahuan hanya dianggap sebagai suatu kumpulan fakta-fakta yang harus dihapal, sehingga model ceramah merupakan model yang paling sering dilakukan oleh para guru. Tetapi pada mata pelajaran akuntansi, model ceramah kurang bisa memberdayakan siswa menjadi lebih paham dan aktif, karena mata pelajaran akuntansi lebih memusatkan siswa kepada logikanya untuk bekerja dalam menyelesaikan soal-soal. Oleh karena itu model pembelajaran kontekstual dipromosikan menjadi alternatif model belajar yang baru, guna meningkatkan hasil belajar siswa. Menggunakan model kontekstual ini, siswa diharapkan belajar melalui apa yang dialami bukan hanya menghafal, karena pembelajaran kontekstual menekankan pada orientasi pengalaman nyata, berpusat pada siswa, kritis, dan kreatif.

Dalam penjelasan yang sudah dipaparkan ini, siswa perlu mengerti apa makna, manfaat, dan bagaimana cara mencapainya kelak. Siswa lebih termotivasi karena mereka mempelajari apa yang bermanfaat bagi dirinya dan berupaya menggapainya. Berdasarkan uraian di atas dijelaskan bahwa model kontekstual merupakan alternatif yang efektif dalam upaya peningkatan hasil belajar siswa.

Hal tersebut sesuai dengan hasil penelitian yang dilakukan oleh Sahuri (2009) bahwa pendekatan contextual teaching learning dan motivasi belajar siswa dapat meningkatkan prestasi belajar siswa, dan Havivianto, Blasius (2012) menyimpulkan bahwa model contextual teaching learning dapat meningkatkan hasil belajar siswa.

\section{Hipotesis Penelitian}

Berdasarkan uraian di atas, maka hipotesis penelitian yang penulis rumuskan adalah "Terdapat perbedaan hasil belajar siswa antara siswa yang mendapat pembelajaran dengan menggunakan model kontekstual dengan siswa yang tidak mendapatkan pembelajaran model kontekstual“.

\section{Metode Penelitian}

Dalam penelitian ini, penulis menggunakan desain penelitian Quasi Experimental Design. Bentuk quasi experimental design dengan jenis kelompok eksperimen dan kelompok kontrol dengan hanya pascates.

Pengambilan sampel menggunakan "purposive sample atau sampel bertujuan, dilakukan dengan cara mengambil subjek didasarkan atas adanya tujuan tertentu. 
Pemilihan sampel berdasarkan kriteria karakteristik, uaitu dilihat dari jumlah siswa pada suatu kelas yang lebih banyak mendapatkan nilai UTS akuntansi dibawah KKM. Kelas XI IPS A dan XI IPS D.

Prosedur eksperimen dalam penelitian ini adalah sebagai berikut:

1. Melakukan persiapan eksperimen yaitu dengan pengujian istrumen kepada kelas diluar sampel. Teknik pengumpulan data yang digunakan dalam penelitian ini adalah teknik tes.

2. Setelah kelas eksperimen diberikan treatment berupa model pembelajaran kontekstual untuk melihat perubahan hasil belajar siswa eksperimen tersebut.

3. Untuk menguji instrumental penelitian ini digunakan uji validitas dan reliabilitas. Analisis data ini digunakan uji normalitas ChiKuadrat.

Hipotesis statisknya adalah :

- Hipotesis $\mathrm{H}_{0}: \mu_{1}=\mu_{2}$ tidak terdapat perbedaan hasil belajar antara siswa yang mendapat pembelajaran menggunakan model kontekstual dengan siswa yang tidak mendapatkan pembelajaran model kontekstual.

- $\mathrm{H}_{\mathrm{a}}: \mu_{1} \neq \mu_{2}$ terdapat perbedaan hasil belajar antara siswa yang mendapat pembelajaran menggunakan model kontekstual dengan siswa yang tidak mendapatkan pembelajaran model kontekstual

Dimana $\mathrm{H}_{\mathrm{o}}$ kita terima dan $\mathrm{H}_{\mathrm{a}}$ ditolak jika - $\mathrm{t}_{\mathrm{t}}$ $\leq t_{h} \leq t_{t}, H_{0}$ ditolak dan $H_{a}$ diterima jika $t_{h} \leq$ $-t_{t}$ atau $t_{h}>t_{t}$, dengan taraf kepercayaan $95 \%$ atau $\alpha=0,05$ dengan $\mathrm{dk}=$ $\left(\mathrm{n}_{1}+\mathrm{n}_{2}-2\right)$

Sedangkan untuk menguji hipotesis menggunakan uji-t dengan uji dua pihak dengan taraf signifikansi sebesar 5\% dengan rumus berikut:

$$
t=\frac{\bar{x}_{1}-\bar{x}_{2}}{s \sqrt{\frac{1}{n_{1}}+\frac{1}{\mathrm{n}_{2}}}}
$$

Dimana $S$ adalah varians gabungan yang dihitung dengan rumus:

$$
S=\sqrt{\frac{\left(n_{1}-1\right) s_{1}^{2}+\left(n_{2}-1\right) s_{2}^{2}}{n_{1}+n_{2}-2}}
$$

\section{Hasil Dan Pembahasan Hasil Belajar Kelas Eksperimen}

Berdasarkan hasil perhitungan dapat dideskripsikan bahwa hasil belajar siswa kelompok eksperimen dan kelompok kontrol berbeda, siswa pada kelompok eksperimen memperoleh nilai rata-rata yang lebih tinggi dibandingkan dengan nilai rata-rata yang didapatkan oleh siswa kelompok kontrol. Hasil post test pada kelompok eksperimen yang diterapkan model pembelajaran kontekstual menunjukkan bahwa siswa yang mendapatkan nilai 60 sebanyak dua orang, nilai 65 sebanyak dua orang, nilai 70 sebanyak enam orang, nilai 75 sebanyak tujuh orang, nilai 80 sebanyak 11 orang, nilai 85 dan 90 sebanyak enam orang. Nilai rata-rata siswa yaitu 78,13 dengan nilai tertinggi 90 dan nilai terendah 60. Dengan kata lain hanya 10 orang yang mendapatkan nilai dibawah KKM.

Pencapaian hasil belajar siswa tergantung pada proses belajar mengajar pembelajaran, guru menyalurkan berbagai materi mengenai akuntansi kepada siswa, tetapi juga siswa perlu menerapan dan mencari informasi materi akuntansi tersebut melalui pengalamannya. Namun pada saat guru menyampaikan materi pembelajaran hanya menggunakan model ceramah dan tanya jawab, maka siswa kurang aktif dalam menggali pengetahuannya sesuai dengan pengalaman siswa tersebut.

Proses belajar mengajar seyogyanya ialah, dimana siswa diberikan kesempatan untuk mendapatkan pengalaman langsung, agar pembelajaran lebih bermakna bagi siswa tersebut. Hal ini yang mendasari pemilihan model pembelajaran kontekstual. Pada model pembelajaran ini siswa dilibatkan secara aktif dalam mempelajari materi dengan cara menghubungkan pada kehidupan nyata siswa. Model pembelajaran kontekstual menekankan pada proses keterlibatan siswa untuk menemukan makna dari materi yang diajarkan.

Proses kegiatan belajar mengajar dengan menerapkan model kontekstual dapat membuat siswa mencari dan menemukan sendiri materi pelajaran. Dalam pembelajaran kontekstual siswa didorong untuk menemukan hubungan antara materi yang dipelajari dengan kehidupan nyata siswa, sehingga materi yang dipelajari dapat dipahami dengan baik, dan dapat menjadi bekal mereka dalam mengarungi kehidupan nyata di masa depan. 


\section{Hasil Belajar Kelas Kontrol}

Berdasarkan perhitungan hasil belajar pada kelompok kontrol, yaitu kelompok yang tidak diterapkan model pembelajaran kontekstual, siswa melaksanakan kegiatan pembelajaran dengan menggunakan model ceramah dan tanya jawab saja.

Pada kelompok kontrol, siswa hanya menerima informasi dari guru, tanpa harus mencari dan menganalisis secara mandiri. Hal ini membuat keadaan kelas kurang aktif dalam menjalani proses pembelajaran, sehingga siswa pun kurang memahami materi yang sudah diberikan oleh guru. Hal ini terlihat pada hasil belajar siswa. Hasil post test kelompok kontrol menunjukkan bahwa siswa mendapatkan nilai 60 sebanyak empat orang, nilai 65 sebanyak lima orang, nilai 70 sebanyak 11 orang, nilai 75 dan 80 sebanyak enam orang, nilai 85 sebanyak lima orang, dan nilai 90 sebanyak tiga orang. Nilai rata-rata siswa yaitu 74 dengan nilai tertinggi 90 dan nilai terendah 60. Dengan kata lain terdapat sebanyak 20 orang yang mendapatkan nilai dibawah nilai KKM.

\section{Pengujian Hipotesis}

Hasil belajar kelompok eksperimen dan kelompok kontrol berbeda, hal ini terlihat ketika hasil post test dari kedua kelompok dibandingkan, dan hasil belajar siswa mengalami perbedaan dengan selisih 4,13 poin pada nilai rata-rata kedua kelas dimana kelompok eksperimen adalah 78,13 sedangkan pada kelompok kontrol adalah 74. Adanya perbedaan hasil belajar yang dicapai siswa dimana siswa kelompok eksperimen lebih unggul dibandingkan kelompok kontrol.

Hal ini terjadi karena pencapaian hasil belajar siswa sangat tergantung pada bagaimana proses belajar mengajar itu terjadi. Dalam pembelajaran akuntansi, pendidik tidak cukup hanya menyalurkan berbagai informasi mengenai akuntansi kepada siswa, tetapi siswa perlu dibekali dengan penerapan materi akuntansi tersebut melalui pengalamannya. Namun pada kenyataannya dalam menyampaikan materi pendidik hanya menggunakan model ceramah dan tanya jawab, sehingga siswa kurang aktif dalam menggali pengetahuannya sesuai dengan pengalamannya.

Proses belajar mengajar yang sangat dianjurkan ialah, dimana siswa diberikan kesempatan untuk mendapatkan pengalaman langsung, agar pembelajaran lebih bermakna bagi siswa. Hal ini lah yang mendasari model pembelajaran kontekstual. Pada model pembelajaran ini siswa dilibatkan secara aktif untuk menemukan makna dari materi yang dipelajari dengan cara menghubungkan pada kehidupan nyata siswa. Dalam arti luas pembelajaran kontekstual yang menekankan pada proses keterlibatan siswa untuk menemukan makna dari materi yang diajarkan dengan adanya pengalaman yang didapatkan oleh siswa.

Proses belajar dengan menggunakan model kontekstual tidak mengharapkan siswa hanya menerima pelajaran, tetapi proses mencari dan menemukan sendiri materi pelajaran. Dalam pembelajaran kontekstual siswa didorong untuk dapat menemukan hubungan antara materi yang dipelajari dengan kehidupan nyata siswa, dan materi yang dipelajari tidak hanya sebatas dipahami atau hanya disimpan dalam otak kemudian dilupakan, tetapi sebagai bekal mereka dalam mengarungi kehidupan nyata di masa depan.

Sementara itu pada kelompok kontrol yang tidak diterapkan model pembelajaran kontekstual, siswa melaksanakan kegiatan pembelajaran dengan menggunakan model ceramah dan tanya jawab saja. Pada kelompok kontrol, siswa hanya duduk manis dan menerima informasi dari pendidik, tanpa harus mencari dan menganalisis secara mandiri. Hal ini membuat keadaan kelas kurang aktif dalam menjalani proses pembelajaran, sehingga siswa pun kurang memahami materi yang sudah diberikan oleh pendidik. Hal ini terlihat pada hasil belajar siswa. Hasil post test kelompok kontrol menunjukkan bahwa siswa mendapatkan nilai 60 sebanyak empat orang, nilai 65 sebanyak lima orang, nilai 70 sebanyak 11 orang, nilai 75 dan 80 sebanyak enam orang, nilai 85 sebanyak lima orang, dan nilai 90 sebanyak tiga orang. Nilai rata-rata siswa yaitu 74 dengan nilai tertinggi 90 dan nilai terendah 60 . Dengan kata lain terdapat sebanyak 20 orang yang mendapatkan nilai dibawah nilai KKM.

Hasil belajar kelompok eksperimen dan kelompok kontrol berbeda, hal ini terlihat ketika hasil post test dari kedua kelompok dibandingkan, dan hasil belajar siswa mengalami perbedaan dengan selisih 4,13 poin pada nilai rata-rata kedua 
kelas dimana kelompok eksperimen adalah 78,13 sedangkan pada kelompok kontrol adalah 74. Adanya perbedaan hasil belajar yang dicapai siswa dimana siswa kelompok eksperimen lebih unggul dibandingkan kelompok kontrol.

Berdasarkan pengujian dengan Uji Barlet diperoleh hasil $X^{2}$ hitung dengan $X^{2}$ tabel, untuk $\alpha=0,05$ dan derajat kebebasan $(\mathrm{db})$ $=\mathrm{k}-1=2-1=1$. Maka didapatkan $\mathrm{X}^{2}$ tabel $=$ 3,641 . Dibandingkan dengan $X^{2}$ hitung $\leq X^{2}$ tabel $=0,897 \leq 3,641$ maka kedua data homogen.

Dari hasil perhitungan uji normalitas, untuk post test kelompok eksperimen $7,71<12,592$, dan untuk post test kelompok kontrol 4,01<12,592. Maka untuk kedua kelompok data berdistribusi normal.

Pengujian hipotesis diperoleh dari hasil perhitungan uji beda rata-rata untuk hasil posttest pada kelas eksperimen dan kelas kontrol, dimana diperoleh $t_{\text {hitung }}$ $(4,26)>t_{\text {tabel }}(1,99)$ hal tersebut menunjukkan bahwa terdapat perbedaan hasil belajar siswa yang disebabkan oleh adanya perbeaan perlakuan pada kelompok eksperimen dan kelompok kontrol.

Dengan adanya perbedaan maka hal tersebut menunjukkan bahwa model pembelajaran kontekstual berpangaruh pada hasil belajar siswa, sehingga model kontekstual ini efektif jika diterapkan pada mata pelajaran akuntansi, khususnya pada kompetensi dasar mencatat transaksi pada jurnal umum.

Hasil penelitian ini sejalan dengan penelitian Sahuri (2009) menyimpulkan pendekatan contextual teaching learning dan motivasi belajar siswa dapat meningkatkan prestasi belajar siswa, Kevin W. Curry Jr, Elizabeth Wilson, Jim L. Flowers, Charlotte E. Farin. (2012) menyimpulakan bahwa contextual teaching and learning dapat di terapkan kepada siswa, dibandingkan dengan model tradisional dalam konsep-konsep ilmiah yang berkaitan dengan pertanian, dan Havivianto (2012) menyimpulkan bahwa bahwa model contextual teaching learning dapat meningkatkan hasil belajar siswa

Tetapi, penulis tidak dapat mengeneralisasikan bahwa model pembelajaran ini efektif diterapkan pada kompetensi dasar lainnya, perlu dilihat juga karakteristik dari materi yang akan disampaikan.

\section{Kesimpulan Dan Saran Kesimpulan}

Berdasarkan hasil penelitian dan tersebut maka dapat disimpulkan, terdapat perbedaan antara hasil belajar siswa yang mendapatkan pembelajaran kontekstual dengan siswa yang tidak mendapatkan pembelajaran kontekstual pada mata pelajaran akuntansi dalam kompetensi dasar mencatat transaksi pada jurnal umum, dengan adanya perbedaan hasil belajar pada kedua kelompok tersebut dapat disimpulkan bahwa model pembelajaran kontekstual berpengaruh terhadap hasil belajar siswa.

\section{Saran}

Berdasarkan hasil penelitian maka saran yang diberikan oleh peneliti dalam penelitian yang dilakukan, sebagai berikut:

1. Berdasarkan hasil penelitian, bagi masing-masing satuan pendidikan dan guru akuntansi dapat menerapkan model pembelajaran kontekstual, karena model pembelajaran ini merupakan salah satu model yang layak untuk diterapkan pada mata pelajaran akuntansi, karena dapat membuat siswa lebih aktif dalam pembelajaran akuntansi, sehingga dapat meningkatkan hasil belajar siswa.

2. Untuk penelitian selanjutnya hendaknya melakukan penelitian mengenai penggunaan model pembelajaran kontekstual ini pada materi yang lain atau bahkan pada mata pelajaran yang lain karena penelitian ini hanya pada satu kompetensi dasar.

2. Untuk peneliti selanjutnya disarankan jika menggunakan desain penelitian kelompok eksperimen dan kontrol dengan hanya pascates, dalam pemilihan sampel menggunakan random sampling agar hasil penelitian lebih akurat, dan rencanakan kegiatan lebih matang .

\section{Daftar Pustaka}


Hamalik, O. (2003). Proses Belajar Mengajar. Jakarta: PT. Bumi Aksara

Havivianto, Blasius. (2012). Penerapan Model Contextual Teaching And Learning (CTL) Untuk Meningkatkan Hasil Belajar Siswa Pada Mata Pelajaran Menggambar Konstruksi Langit-Langit.

Skripsi.

Bandung:Program Sarjana UPI

Kevin W. Curry Jr, Elizabeth Wilson, Jim L. Flowers, Charlotte E. Farin. (2012). "Scientific Basic vs. Contextualized Teaching and Learning: The Effect on the Achievement of Postsecondary Students". Journal of Agricultural Education. Volume 53, Number 1, pp 57-66

Marlina. (2011). "Model Contextual Teaching and Learning(ctl) pada Perkuliahan Dasar Rias (Tata Kecantikan Wajah dan Rambut) untuk Meningkatkan Kreativitas Mahasiswa", Jurnal Penelitian Pendidikan. Vol. 12 No. 1

Purwanto. (2008). Psikologi Pendidikan. Bandung: Remaja Rosda Karya.

Sahuri. (2009). "Pengaruh Pendekatan Contextual Teaching and Learning (CTL)

dan Motivasi Belajar Siswa Terhadap Prestasi Belajar", Equilibrium, Vol 5, No 9.

Sagala, Syaiful. (2006). Konsep dan Makna Pembelajaran. Bandung: Alfabeta

Sanjaya, Wina. (2006). Strategi Pembelajaran Berorientasi Standar Proses Pendidikan. Jakarta:Kecana.

Sekaran, Uma. (2006). Research Methods For Business. Jakarta: Salemba Empat

Siregar, S. (2004). Statistik Terapan untuk Penelitian. Jakarta: PT Grasindo

Slameto. (2010). Belajar dan Faktor-Faktor yang Mempengaruhinya. Jakarta: RinekaCipta.

Sudjana, Nana. (2006). Penelitian Hasil Proses Belajar Mengajar. Bandung: Remaja Rosdakrya

Syah, M. (2003). Psikologi Belajar. Jakarta : PT.Rajagrafindo Persada
Wahab, A (2009). Metode dan Model-Model Mengajar. Bandung: Alfabeta 